\title{
The metaphor of light embedded in the Johannine prologue, Part 1: The Light before the incarnation
}

\begin{abstract}
Authors:
Dirk G. van der Merwe ${ }^{1}$

Pierre Y. Albalaa ${ }^{1}$

\section{Affiliations:}

${ }^{1}$ Department of Christian

Spirituality, Church History

and Missiology, University of

South Africa, South Africa
\end{abstract}

Correspondence to:

Dirk van der Merwe

Email:

dirkvdm7@gmail.com

Postal Address:

189 Kotie Ave., Murrayfield

0184, Pretoria, South Africa

\section{Dates:}

Received: 21 Nov. 2011

Accepted: 09 Mar. 2012

Published: 19 June 2013

How to cite this article: Van der Merwe, D.G. \& Albalaa, P., 2013, 'The metaphor of light embedded in the Johannine prologue, Part 1: The Light before the incarnation', In die Skriflig/In Luce Verbi 47(1), Art. \#108, 10 pages. http://dx.doi. org/10.4102/ids.v47i1.108

Note:

Pierre Y. Albalaa was a research associate of Prof. Dirk G. van der Merwe in the Department of New Testament at the University of South Africa.

\section{Copyright:}

(C) 2013. The Authors. Licensee: AOSIS OpenJournals. This work is licensed under the Creative Commons Attribution License.

Read online:
This is the first of two articles on how the Fourth Evangelist has ingeniously embedded the light metaphor in the prologue of the Fourth Gospel. The prologue is replete with this metaphor. A thorough discourse analysis explores the text's inner texture to determine the rhetoric and network of semantic relations, regarding light as the subject. From here the text's sacred texture is investigated. Various theological themes are interwoven into the text, with light being a consistent, embedded metaphor, embracing a wealth of facets and interpretations. This research focuses on the embedded light metaphor in the Johannine prologue as it relates to the Logos's ontological identity and functionality before his incarnation.

Die metafoor van lig ingebed in die Johannese proloog, Deel 1: Die Lig voor die Inkarnasie. Hierdie is die eerste van twee artikels om aan te toon hoe die vierde Evangelis vindingryk die lig-metafoor in die proloog van die vierde Evangelie ingebed het. Die proloog is gevul met hierdie metafoor. Deur middel van ' $n$ behoorlike diskoersanalise is die diepte-struktuur van die teks ondersoek om die retoriek en netwerk van semantiese verhoudings vanaf die perspektief van lig as onderwerp te bepaal. Hierna is die teologiese-struktuur van die teks ondersoek. Verskeie teologiese temas is in die teks verweef, met 'lig' as ' $\mathrm{n}$ konstante verankerde metafoor wat ' $\mathrm{n}$ rykdom van fasette en interpretasie insluit. Hierdie navorsing fokus op die ingebedheid van die lig-metafoor in die Johannese proloog soos wat dit verband hou met die ontologiese identiteit en funksionaliteit van die Woord voor die inkarnasie.

\section{Introduction}

On first reading, the Fourth Gospel (hereafter FG) seems straightforward and easy to understand. However, a careful study of the text reveals more than first meets the mind's eye. Features of the Fourth Evangelist's (hereafter FE) writing are the underlying themes embedded in the text, for example his use of double entendre (double meaning), his cyclic reasoning and many chiastic structures. The FG and prologue contain various well-organised, pictorially interwoven, theological themes that lend themselves to interpretation.

This research emphasises the positive theological exposition of the prologue from the perspective of the prevailing light concept. The objective is firstly to indicate the comprehensive embeddedness of the light metaphor in the Johannine prologue, and secondly to highlight the many features of the light metaphor. Finally, this investigation shows how the light metaphor connects major themes in the prologue - light being one of the key theological themes of the prologue. We examine the identity and function of light before the incarnation of the Logos with a view to gaining a better understanding of the prologue and the rest of the FG.

A dual approach will be followed: (1) a discourse analysis of the text to identify the various semantic overtones regarding the light metaphor, and to structure the research, and (2) a theological reading to correlate and interpret these semantic overtones. ${ }^{1}$

\section{An inner-textural and sacred-textural reading of the prologue An orientation to inner-textural and sacred-textural reading}

The purpose of the inner-textural analysis of the prologue's text is to gain in-depth knowledge of the text's words, word patterns, voices, structures, devices and modes. This forms the context for meaning and interpretation (Robbins 1996:7). In this article, the discourse analysis helped to highlight the different semantic relations between words and concepts and to determine the rhetoric of the FE in this text.

1.The inner-textural and sacred-textural readings of a text are textures used in the socio-rhetorical methodology as developed by Vernon Robbins (see Robbins 1996). Another scholar, Duane Watson, is working in collaboration with Robbins on this methodology. In my usage of this terminology I do not comply with the way Robbins and Watson use it. For me it is just an indication and reference to work with the text (inner-texture) and the theological discourse (sacred-texture) generated by the text. The reference to a 'dual approach' only refers to the abovementioned two approaches that will be exploited in this research. 
At a stylistic level, the movement of thought and the technique which the FE uses influence the whole research process. In the prologue (and discourses) he uses the technique of verbal links through keywords, concatenation of ideas by means of recourse to earlier ideas, and inclusio whereby thought is brought back to its starting point (Schnackenburg 1980:115f.). The FE's train of thought also revolves around certain concepts, but moving forward despite its circular motion. The FE's pattern of thought is almost spiral: although thoughts circle and return, they still progress to a higher, more explanatory, level. This meditative way of thought uses few arguments but proceeds progressively deeper into its subject to gain better and higher understanding (Schnackenburg 1980:116f.).

The sacred-texture will help to locate the ways the text speaks about God and the Logos who are also presented as the Light (cf. Robbins 1996:120). At a theological level, Van der Watt (1995:91-126) makes a useful contribution to the structural exposition of Johannine theology (see also Loader 1984:188216) which he indicates as a 'pictorial representation'. He indicates how the Johannine thought system (Christology, soteriology, ethics, pneumatology and eschatology) which is organic-systematic in character can be presented pictorially. The different themes are linked organically and recall one another systematically for they are spread throughout the FG. He emphasises that:

Johannes telkens uit die teologiese bedding wat sistematies saamhang, geput het en die temas konsekwent deur die Evangelie aangebied het. Dit kan ook as verklaring dien waarom dieselfde temas deur die loop van die Evangelie telkens na vore tree en waarom Johannes verkies om met ' $n$ beperkte aantal temas te werk. In die piktorale samehang is die temas nie logies-opeenvolgend (kettingagtig) gestruktureer nie, maar logies verbandhoudend (piktoraal). [John often uses themes from his theological bed, which systematically coheres. He then presents these themes consistently throughout the Gospel. This clarifies why similar themes occasionally occur throughout the Gospel and also why John prefers to work with a limited number of themes. In this pictorial coherence the themes are not structured logically-consecutively but logically related.] (Van der Watt 1991:93-126)

Meeks's (1972:68) earlier perception supports Van der Watt's hypothesis when he says: '[ $t$ ]he reader cannot understand any part of the FG until he understands the whole'. Koester (2008:3) supports the view of Van der Watt and Meeks: ' $t$ t]he present form of the Gospel can rightly be read as a whole'. Each time, this organic-systematic pictorial structure forces the exegete to view every specific theme against the background of other themes.

\section{The inner-textural reading of the Johannine prologue}

A brief investigation of the prologue begins with a discourse analysis to highlight the semantic relations and rhetorical arguments of the FE in the text. This is necessary to prevent any form of repetition in the case of critical analysis, to determine the focal point that constitutes the lens through which the interpretation and understanding of the semantic relations of the prologue will be conducted, to determine the rhetoric and contemplation of the FE, to point out the comprehensive embeddedness of the light metaphor, and to create a logical perceptible profile of the Light, before the incarnation, as a conceptual system used by the FE in the prologue.

In recent decades, many studies have proved that a kind of symmetry pattern or structure, which clearly forms a chiasmus, is discernible in the prologue. ${ }^{2}$ The results of these studies provide evidence that the structure of the prologue is chiastic. The different criteria used to construct the chiasmus end up in different chiastic structures.

Thus, the prologue can be divided into two main sections, each having its own structuring principles (Van der Watt 1995:329-331). In each section, at least three 'actors' are mentioned, and their actions are repeated. This infers that events like the witnessing of John the Baptist, the incarnation of the Son and his presence with the Father are narrated twice.

See the addendum at the end of this article for a discourse analysis of the Johannine prologue, in chiastic structure, conducted from the perspective of the light metaphor.

\section{An explanation of the proposed chiastic structure}

From the perspective of the light motif, the above chiastic structure $^{3}$ can be presented, briefly and pictorial-logically, as follows: ${ }^{4}$

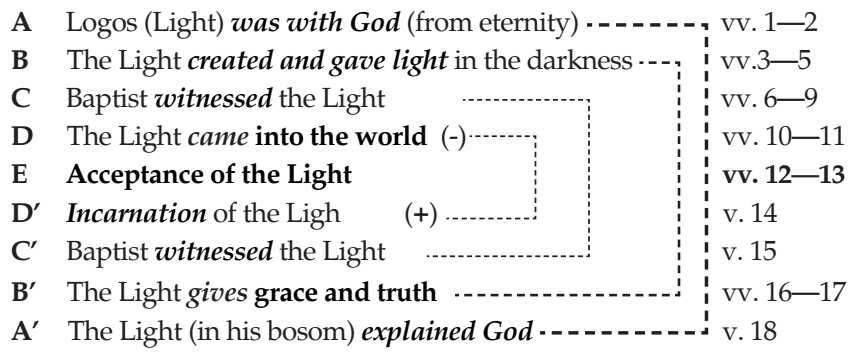

The pivot ${ }^{5}$ of this prologue, and that of the above chiastic structure, $^{6}$ is to be found in cluster E (vv. 12-13) ${ }^{7}$. This

2.Boismard (1957), LaMarche (1964), Borgen (1970), Hooker (1970), Culpepper (1981), Van der Watt (1995), Keener (2003) and Neyrey (2007:38-41), to name a few, believe that the prologue is chiastic. In their investigation, each one follows different criteria and considerations, and accordingly proposes their chiastic structure of the prologue.

3.Van der Watt (1995:330) bases the division on the order of the appearance of the 'characters' and the time in the salvation history, which they represent. For him the important figures are structurally related. Culpepper (1981:8) bases his chiasmus on the following three criteria: language, concepts and content. Although based on the semantic relations proposed by us, this chiastic structure looks similar to on the semantic relations proposed by us, this chiastic structure looks similar to
that proposed by Brown (1966:3) who based his structure on a poetic hymn (which he did not see as chiastic) as composed in the Johannine church. This structure is also closely related to the text of the New American Bible with only a few structural
differences.

4.The explanation and verification of how and why these semantic clusters relate to each other will not be repeated here but are available in the unpublished dissertation of Albalaa (2007:75-77).

5.There is no agreement among scholars as to where the centre of the chiasmus should be exactly. Nevertheless it is widely accepted that it lies in the vicinity of verses 10-13. Culpepper (1981:4-8) unconvincingly goes too far in forcing verses 11 and 13 into a chiastic relation in order to make 12.1 the pivot of the prologue. Van der Watt (1995:331-335) rejects the reference to a 'central theme' in one single verse in the prologue. Hengel (2008:268) determines verse 14 as the climax and goal.

6.Also see the discourse analysis of Hengel (2008:293-294).

7.Verse 12 describes the responsibility of humankind in the redemption process. Verse 13 depicts what is happening simultaneously during this same process from the divine perspective. 
then implies that the rest of the prologue has to be viewed semantically or interpreted through the lens of redemption, which comprises the enlightenment of people. The fact that the Logos met with misunderstanding and rejection from humans when he came into the world is now contrasted with the fact that there were still some who 'received him' ö $\sigma 01 \delta$ غ

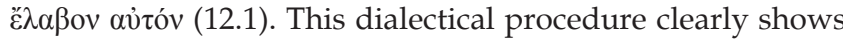
the hand of the FE (Schnackenburg 1980:261).

The chiasmus serves to link these two sections and to show that the same important matters are dealt with in both of them, but from different perspectives. Two perceptions of the same reality are given. In the first section (vv. 1-11) historical events are described chronologically. To establish their true significance, these historical events should be seen from the divine perspective of grace and truth (vv. 14-18).

This investigation will not follow the structure of the chiasmus sequentially, but rather the semantic cluster network as indicated in the discourse analysis. The focal points of these clusters are the following:

1. The Word, who is God, is also the Light.

2. The Logos (who is the Light) reveals God.

3. The Light created the world into which He came.

4. The Baptist witnessed the Light.

5. The Light came into the world.

6. The Light shines in the darkness so that His glory could be seen.

7. The darkness could not overwhelm the Light.

8. The Light brings salvation.

The different clusters of semantic relations $(\mathrm{a}-\mathrm{h})$ clearly and convincingly point out how the entire prologue is saturated with the light metaphor. Each of these clusters is connected with some aspect or nuance of the light metaphor. The following subsection substantiates this further in discussing the profiles of clusters a-d. ${ }^{8}$

\section{Conclusion}

The discourse analysis with the indicated semantic combinations convincingly points out how the light metaphor is embedded in the prologue of the FG, with the result that the entire prologue is filled with this notion. This facilitates an investigation of the theological texture to construe the pictorial $^{9}$ theological interwovenness and to understand the prologue as an illumination-oriented construct.

\section{A sacred-textural reading of the discourse analysis of the prologue ${ }^{10}$}

The following is a concise discussion of the semantic relations indicated above and their theological meaning and implications from the perspective that Jesus Christ, the

8.This first article of two will focus on the semantic clusters $a, b$ and $d$

9.See footnote 1 .

10.Please note that all the text references regarding the prologue are according to their use in the discourse analysis. The sequence of the discussion of the eight identified concepts through the semantic relations in the discourse analysis does not follow the sequence of the chiasmus and text. The sequence to be followed is that of the logical flow of events. only Son of God, is the Logos or Light, who came to reveal (enlighten) and to save (lighten).

\section{The Word, who is God, is also the Light (cluster $\mathrm{f}$ )}

The prologue starts by setting Jesus' ministry in a cosmic framework (Koester 2008:8). Therefore, this subsection investigates the relationship between the following concepts: Logos, God, Life, Light, only Son of God or the Father, and Jesus Christ.

\section{Semantic relations:}

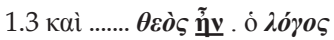

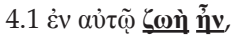

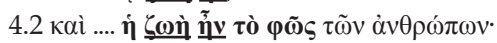

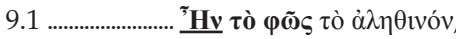

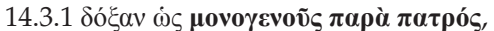

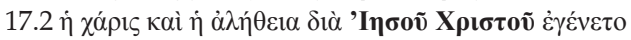

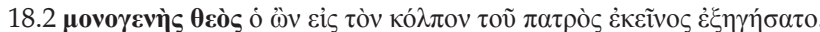

The semantic relations in the first cluster are created by the multiple occurrences of the verb $\tilde{\eta} v$. The prologue associates the Logos with God, life and light (in the second cluster also with 'the only Son of the Father' and with 'Jesus Christ'). This association governs the entire narrative.

Interpretation of related texts: ${ }^{11}$ In the prologue, the readers of the FG understood the meaning of certain terms - such as Logos, life, light and darkness - because these were words drawn from everyday language. But in both the original Greek text and the English translation of the prologue, these terms do not denote or mean what they do in everyday language. In the prologue, they are used to refer to some qualities of a person, namely the only Son of God (14.3.1; 18.2) or Jesus Christ (17.2). In everyday language, 'words' do not 'become flesh', nor do they possess the property of 'glory' (Petersen 1993:8).

Thus, the FE is using everyday language but in a special way; this is implicitly and explicitly contrasted with everyday usage. In this regard it can be said that he is using a special language (Petersen 1993:9). What happens here is that the FE employs metaphors in some cases because metaphors can be used non-contradictorily to say one thing is another (Petersen 1993:10), for example 'the life is the light' (4.2). But in verse 5 it is different. ${ }^{12}$ In verse 5 the FE writes, ' $[t]$ he light shines in the darkness and the darkness has not overcome it', ${ }^{13}$ and in verse 9 he makes a parallel assertion that the true light that enlightens every $\operatorname{man}^{14}$ was coming into the world; he

11.This subsection is very much embedded in the work of Petersen (1993:8-22). Yet there are various points that differ from his. For example, he tries to prove that there are various points that differ from his. For example, he tries to prove that literally. This is a fallacy bese the life and light) have to be understood only literally. This is a

12.Bultmann (1978:40) is correct in that in verse 5 light is not spoken of figuratively Iso see pages $40-45$ on the varieties of the usage in the FG. For further discussion on distinguishing between figurative and literal usage, see Conzelmann (1974:349353).

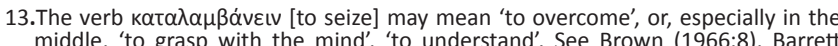
(1975:132), Keener (2003:387) and Lincoln (2005:99) for an elaborate discussion. (1975.132), Keener (2003.387) and Lincoln (2005.99) for an elaborate discussion. According to Barrett (1975:132), the FE may well be playing on the two meanings.

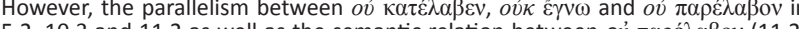

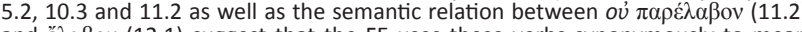
and $\check{\varepsilon} \lambda \alpha \beta$ ov (12.1) suggest that the FE uses these verbs synonymously to mean 'receive' or 'understand'. See Bultmann (1978:48) on synonyms in the prologue.

14.Keener (2003:385) points out that Jesus as the Word of God and as Wisdom and Torah is light to enlighten the people of God, just as the Torah was light that was offered to the people of God at Sinai. 
was in the world ... yet the world knew him not ... and his own people received him not'.

The statement the light shines in the darkness and the darkness has not overcome it' does not need to be construed metaphorically. Only when verse 5 is read along with verse 9 does the possibility of metaphor arise. The light shining in the darkness (5.1) could be a metaphor for light coming into and being in the world (9.1.1.1). 'Shining' could be a metaphor for 'coming into' (9.1.1.1), 'being in' (10.1), whilst 'darkness' could be a metaphor for the world. Thus, 'the world' would be assigned the attribute of 'darkness' but would not be darkness, and 'coming into' and 'being in' would be given the attribute of shining without being shining (Petersen 1993:11).

Difficulties arise when it becomes clear that light is the subject of both statements. In verse 5.1 light seems to denote solar light, to which 'shining' and 'in the darkness' fit conventionally. In verse 9 light is anthropomorphised. This is substantiated by expressions such as 'coming into' (9.1.1.1), 'being in' (10.1), 'was made through him' (10.2), 'he came to his own home' (11.1), and 'his own people' (11.2). Consequently, the statement in 5.1 is not a metaphor for the one in 9.1 but rather vice versa: 9.1 is an anthropomorphic metaphor for the statement in 5.1. The question arises here: What is the FE referring to in 5.1 when he speaks of light? It is clear that he has not used the word metaphorically (Petersen 1993:12). Does it then mean that he is using it literally and, if not, what is he trying to refer to? Or is it a typical Johannine appearance where the word is used in a dualistic capacity of being a metaphor in one sense and not a metaphor in another sense? To have clarity on these questions, verses 3-4 had to be incorporated into this discussion.

Life in 4.1 could be understood as residing in Logos and being involved in creation. The personal pronoun in 4.1 relates to the personal pronouns in 2.1 and 3.1. Due to the fact that the FE refers to Jesus throughout the gospel as Logos, ${ }^{15}$ the Light, and the Life (Jn 1:9-11, 14; 8:12; 11:25), verse 4 could be understood as inferring that Life, like Light and Logos (all three capitalised), was 'in Logos'16 and that 'the Life was the Light for men' ${ }^{17}$ Further, 'Life' and 'Light' could be understood as metaphors respectively used for Logos. In this sense the quality of life will be attributed to Logos, and the quality of light would be attributed to life. This means that Logos has to have a literal reference to whatever the FE intends this expression to refer to, because it would be metaphorically granted the quality of life, which word will now have to be un-capitalised. However, when one reads that 'the Life was the light of men' (4.2), 'Life' would have to be capitalised and understood to be a literal reference, for now the un-capitalised light would be a metaphorical attribute of 'Life'. Consequently 'Logos' would refer literally, 'the Life or

15. The Son in Jesus as God's Logos, Wisdom and Torah, is light to enlighten God's people. Light is universally acknowledged as a symbol of life itself and of the human mind with its self-consciousness. In biblical tradition the imagery of light is used to describe the existence, presence and abode of God, and the creative and saving acts of God. Also the revelation of God Creation, Wisdom and Torah are described in terms of light (Ps 119:105, 130; Pr 6:23). See also Dodd (1963:84), and Keener (2003:385).

16. In his comparison of commentaries, Cahill (1976:54) generated the hypothesis that the usage of 'Logos' in the Johannine prologue is a case of centring.

17.Throughout the FG light and life are closely associated (Malina \& Rohrbauch 1998:31). life' would refer both literally and metaphorically, and 'the light' would only refer metaphorically. But in verse $9.1 \varphi \tilde{\omega} \varsigma$ is personalised to relate literally to life in 4.2 . Thus, it can be deduced that if 'Logos' and 'God' refer literally, so could 'the Life' and 'the Light' (Petersen 1993:13).

In the above discussion of the relation between verse 5 and verses 9-11, it has been pointed out that 'the Light' does refer literally. Viewed as such, 'the Life' could be 'in' the 'Logos' just as the Logos was 'with' God, and the Light 'being' the Life of men could be understood in terms of the Logos 'being' God. In this sense, 'the Logos', 'God', 'the Life' and 'the Light' could all be used synonymously to refer literally to the same referential entity. This is also comprehensible from the comparison between the statements in verses 3.1 and 10.2 (Petersen 1993:13).

The synonymity of 'the Logos' and 'the Light' (and 'the Life' by implication) is further established by the fact that in the prologue creation happened through their involvement:

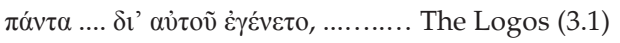

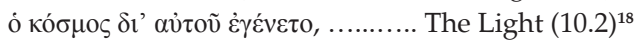

Because the one creation of 'all things' or 'the world' is attributed to both 'the Logos' and 'the Light', the latter two expressions are used synonymously to refer to the same referent. This is substantiated even further by the fact that Jesus is (implicitly) both 'the Logos' in its incarnate form (v. 14) and 'the Light' as it appeared in the world. The same can be said of 'the Life'. If the verb was ( $\tilde{\eta} v)$, in 4.1, is taken as a

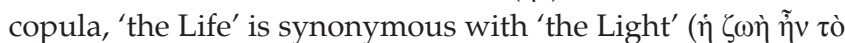
$\varphi \tilde{\omega} \varsigma, 4.2)^{19}$. This interpretation is further supported by the fact

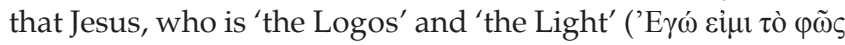

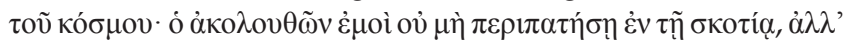

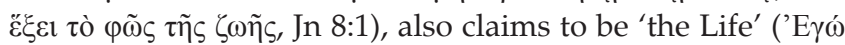

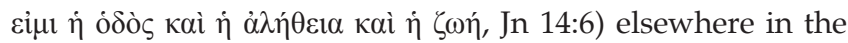
FG. Because of this synonymity, the four expressions about Jesus Christ (Logos, God, Life, and Light) are synonymous ${ }^{20}$

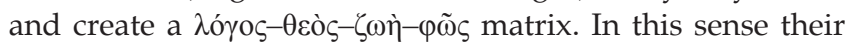
reference is literal, not metaphorical, and they each refer to

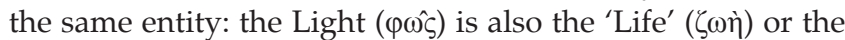

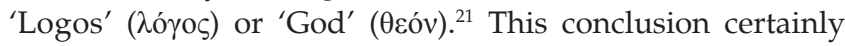
has important implications for the rest of this study. It infers

18. Also confer the predicated light, refers to God as light and the archetype of all other kinds of light. He (Alleg. Interp. 3.25-26; Planting 9) also refers to the Logos as the source of light and life.

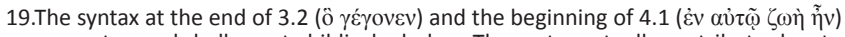
presents a real challenge to biblical scholars. The syntax actually contributes less to the $\mathrm{FE}$ identifies 'life' (1) context contributes, since the FE identifies 'ife' ( $\zeta \omega \eta)$ ) with light $(\varphi \tilde{\omega} \varsigma$, In $1: 4 ; 8: 12)$, whilst light contextually refers to Jesus Christ (Jn 1:9-10), then at a functional level, life is ultimately Jesus himself (Jn 11:25; 14:6). This is emphasised in the body of the gospel in Jesus's declaration that 'as the Father has life in himself so he has granted the Son also

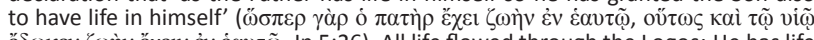

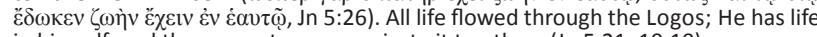
in himself, and the power to communicate it to others (Jn $5: 21 ; 10: 10)$

20.In verse 14 the FE equates the 'glory of the Logos' (14.3) with the 'glory of the only

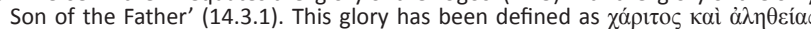

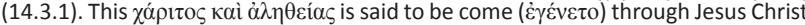

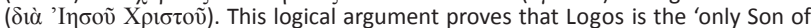
the Father' and He is also Jesus Christ. Thus Logos, God, Life, Light, only Son of God, and Jesus Christ refer to the same entity.

21.It is at this point in time that divergence starts to creep in concerning Petersen's (1993:14) interpretation. For him the literal meaning is absolute; there is no room either for simultaneous metaphorical understanding. If this is true, then why did the FE not only continue using Logos when referring to the only Son of the Father? the FE not only continue using Logos when referring to the only Son of the Father?
Certainly, the words 'Logos', 'life' and 'light' not only refer to the same entity, but metaphorically also to certain qualities and functions of the only Son of God. 
and legitimises that everything written in the prologue can be interpreted and understood from the perspective of light.

However, the light concept is also used metaphorically, and this usage is constituted by its combination with 'darkness' and also with the relation between light and life. ${ }^{22}$ In verses 4 and 5, light and darkness metaphors are used for the first time in a cosmic framework. The Logos as the Life and the Light takes up a position over and against darkness as a symbol of the evil stubbornness of the world, which rejected him (v. 5, 8-9). ${ }^{23}$ According to this metaphor, light reveals the power of God. ${ }^{24}$ It emanates from the Logos, and manifests the life given to people through him. The Life referred to here is divine life, the primary source of all life, natural and supernatural. It has a theological dimension which is God's relationship to human beings, and a physical dimension since the Logos was the absolute creative power through which 'all things' came into being and nothing was created without him (v. 3). This Life is the light of men, for from the Logos they receive the light (v. 9), the light of grace and truth (v. 17). ${ }^{25}$

Conclusion: This subsection dealt with the nature and character of the Light, which is personified in Jesus Christ. On the one hand it has been characterised in terms of the

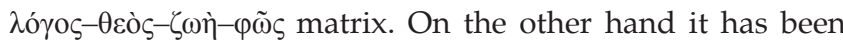
indicated that the metaphorical application of light occurs in its combination with darkness and the relation between light and life.

\section{The Logos (who is the Light) reveals God (cluster d)}

This section investigates the close semantic relationship between verses 1-2 and 18. The relationship between the Logos and God is examined to provide a better understanding of the nature of the 'light metaphor'. Although there are no explicit references to 'light' $(\varphi \tilde{\omega} \varsigma)$ in this text, it is metaphorically and

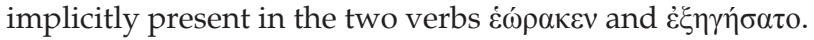

\section{Semantic relations:}

\section{$1.1{ }^{\prime} E v \dot{\alpha} \rho \chi \tilde{\eta} \tilde{\mathbf{n}} \mathbf{v} \mathbf{o} \boldsymbol{\lambda o ́} \gamma \mathbf{o} \varsigma$}

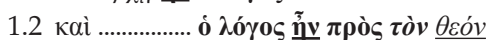

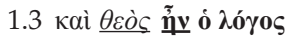

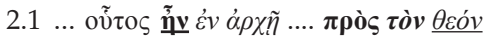

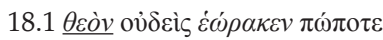

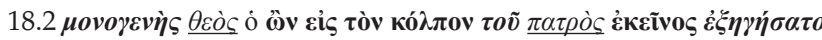

There is a remarkable correlation between verses 1-2 and 18 . Reading them together, it seems as if verses 1-2 prepare for

22. Light and life were natural images to use together. The Son comes into the world as the Logos who brings life from the Father, and as the Light who reveals the Father and the Father's gift of eternal life. See Mullins (2003:58). Such conjoining also occurs in Hebrew poetry (Jb 3:20; 10:21-22; 17:13; 18:18; Ps 36:9; 107:10, 14).

23.In verse 5.1 'darkness' appears to represent a state of condition and in 5.2 a power Both are negative in character. They are opposite to the illumination that the Light generates (Waetjen 2001:270).

24. In the conflict between light and darkness, the reader is already assured that light will win (Malina \& Rohrbauch 1998:31)

25.Kruse (2003:63) notes that the FE did not make it clear how the divine life in the Logos illuminated human beings. Kruse also mentioned two suggestions of two different groups of scholars: firstly this verse relates to the creation of human beings in the image of God, and secondly it refers to the light of general revelation. making sense of verse 18. Because the function of the Son

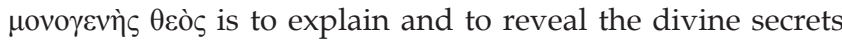
of the Father (Brown 1966:18), the FE prepares the reader in $1-2$ by characterising the Logos, which he identifies later on as the only Son of the Father (14.3.1). The fact that the Logos

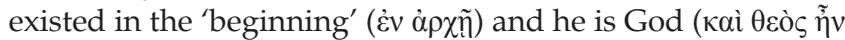

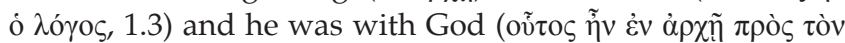
$\theta \varepsilon$ óv, 1.2 ; 2.1) explains why he could have had such a close

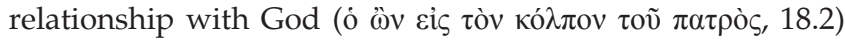

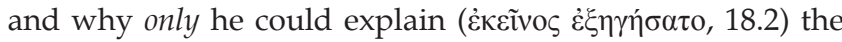

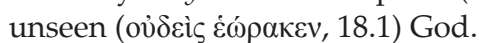

Interpretation of related texts: This subsection tries to point out how the prologue is saturated with references to Jesus's relationship with God. This is necessary to legitimise the truth of his revelation (enlightenment) about the Father in this world. The prologue starts with the expression 'Ev $\dot{\alpha} \rho \chi \tilde{n}$ $(1.1 ; 2.1)$. It is the same as that of the LXX version of Genesis $1: 1{ }^{26}$ The parallel continues into the next verses. 'Beginning' alludes here to the beginning of creation (Col 1:16; Heb 11:3). ${ }^{27}$ Other Genesis allusions such as life, light, darkness and explicit reference to the creation of the world (Gn 1:3) reinforce this point. Thus, 'beginning' refers here to the period before creation and is a designation, more than temporal, of the sphere of God (cf. Schnackenburg 1980:233). ${ }^{28}$

To emphasise the pre-existent life of the Logos in eternity with God, the FE repeatedly (seven times) uses the verb $\tilde{\eta} v$ (v. $1,2,4,8)$, the imperfect of the verb 'to be' in its absolute and predicative uses. This verb ( $\tilde{\eta} v)$ expresses an ongoing event (Hengel 2008:275). Its significance is reflected constantly in the 'I am' ('E $\gamma \omega$ c siul) proclamations of Jesus where he refers to himself in terms that recall the revelation of the divine name to Moses at the burning bush. This infers that the Logos existed, in eternity, before the beginning, outside of time and space (Whitacre 1999:50; Burridge 2007:293). ${ }^{29}$ The attention of the reader is drawn beyond creation and directed into the life of God to encounter the pre-existent Logos. The prologue begins its account in eternity with the Father, showing that the Logos who became the human being (14.1), Jesus Christ (17.2), already existed in the beginning (Mullins 2003:48).

To inform the readers about the relationship between $\lambda$ ó $\gamma$ and $\theta \varepsilon$ ò the FE wrote that $\lambda$ ó $\gamma o \varsigma$ is 'with God'. ${ }^{30}$ The phrase

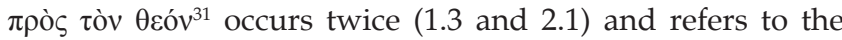

26.Brown (1966:4); Ridderbos (1997:23); Malina \& Rohrbauch (1998:31); Whitacre (1999:49); Mullins (2003:48); Riches (2005:69); Burridge (2007:293). Borgen $(1970: 288-295)$ argues that the prologue is an exposition of Genesis 1:1ff.

27.See Keener (2003:365) for more references. Lincoln (2005:94) has a different viewpoint: according to him, 'beginning' refers to the absolute beginning in the viewpoint: according to him, 'beginning' refers to the absolute beginning in the
sphere of God. See other occurrences of $\alpha \rho \chi \tilde{n}$ in John $2: 11,8: 25,25: 27,16: 4$ and sphere of God. See other occurrences of $\alpha \rho \chi \tilde{n}$ in John $2: 11,8: 25,25: 27,16: 4$ and
$6: 64$. Du Rand (2000:243-259) connects the creation in John 1:1-3 with the new 6:64. Du Rand (2000:243-259) connects the creation
creation and argues that Christ is involved in both.

28.Bear in mind here the introduction of Mark: 'The beginning of the Gospel of Jesus Christ'. See also Brown (1966:4); see also the introduction of 1 John. Riches (2005:69) points out the incomprehensibility of 'beginning'.

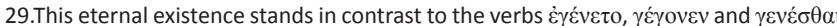
(came to be), which illustrate the finite existence of all creation, and all human beings who 'came to be'.

30.See Phillips (2006:151-152) for a discussion of the meaning of $\pi$ pò $\varsigma$ with the accusative.

31.Despite the strange present participle ó $\omega v v(18.2)$, this phrase is a variant on $\pi \rho{ }^{\circ} \varsigma$ tòv $\theta \varepsilon$ óv in verses $1-2$. What is envisaged here is the intimate relationship between

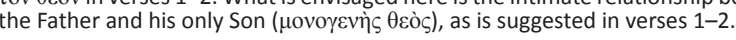


personal distinctiveness of the Logos with God, which has

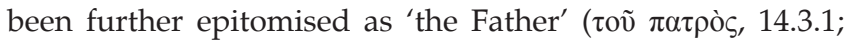

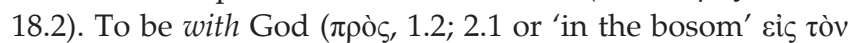
кó $\lambda \pi \mathrm{ov}, 18.2$ ) means that the Logos (Son) is distinct from him. This second affirmation speaks also of the personal union of the Logos with God (Schnackenburg 1980:233). The FE uses the preposition $\pi \rho$ ò $\varsigma$ in such a context to indicate personal relationship. He repeatedly emphasises Jesus's intimacy with the Father, sometimes in the language of him being in the Father (Jn 3:2; 8:29; 16:32; 17:20-23), as Jesus also is with his disciples (Jn 11:54; 13:33; 14:9; 15:27; 16:4; 17:12). ${ }^{32}$ The Logos of the FE has a special relationship with God: it is indicated in part by the preposition $\pi \rho$ ò $\varsigma$ with the accusative,,$^{33}$ and more by the continual reaffirmations of their close relationship throughout the FG. The image of father-son is depicted in this gospel as that of a perfect, ideal father-son relationship (Jn $8: 29,35-38) .^{34}$ The recapitulation of the Logos to be identified as with God in verse 2 emphasises the intimacy of the Father and the Son in the beginning and at creation (Jn 1:3; 8:58) ${ }^{35}$ Hence, the pre-existence of the Logos 'with God' ( $\pi \rho$ ò $\varsigma$ tòv $\theta \varepsilon o ́ v, 1.2 ; 2.1)$ signifies not only 'accompaniment' or 'presence

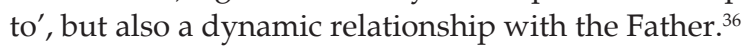

The extent of the perfect revelation by the Son is inferred in

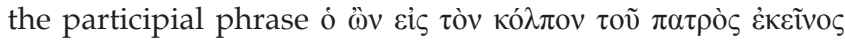
$\dot{\varepsilon} \xi \eta \gamma \tilde{\sigma} \sigma \tau$ (18.2; see also Jn 3:11-13). Here the FE employs figurative language to emphasise the absolute intimacy between the Father and the Son. The conjunction of 'whilst

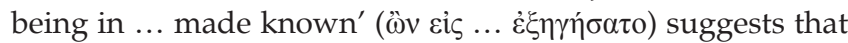
the Son revealed the Father whilst remaining in his bosom. The context confirms that this revelation coincides with his earthly life, which reaches its climax on the Cross. ${ }^{37}$ Holding an object to one's bosom declares the specialness of that object, and indicates an intimate connection. The intimate connection between the Father and Son is not only relational, but it also exists in terms of their shared nature and similar role. The prologue thus culminates in a rehearsal of Jesus's deity, closing an inclusion that began with 1.3.

Therefore, the ambiguous verb $\dot{\varepsilon} \xi \eta \gamma \eta \dot{\sigma} \sigma \alpha \mathrm{o}^{38}$ is used to refer to how the Son revealed the Father in the world. Elsewhere in the NT, it means 'to rehearse fact' or 'to recount a narrative' (Lk 24:35; Ac 10:8; 15:12, 14; 21:19). ${ }^{39}$ The FE uses a verb,

32. Wisdom texts celebrated the special relationship between God and his Wisdom: it dwells with Him (Wisdom 8:3), and was present with Him when he made the world (Wisdom 9:9). See Keener (2003:370) for more detail.

33.Morris (1985:76); Keener (2003:370).

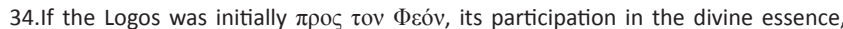
resulting in its identity as $\theta \varepsilon$ có, bears immediate consequences for the character of the work it performs. Therefore, everything generated through the agency of the togos bears the stamp of divine quality (Waetjen 2001:270).

35.Barrett (1975:127); Keener (2003:366).

36.See Brown (1966:5) for a discussion on meaning possibilities and different understandings.

37.Keener (2003:424); see also the $\delta$ ó $\xi \alpha$ motif in John 17:1-5.

38.Louw and Nida $(1993: 99, \S 8.39)$ point to the intimacy in the relationship as 'an association of intimacy and close affection' and as 'to be closely and intimately associated with the implication of strong affection' (p. 448, §34.18). See also Phillips (2006:218).

39.Louw and Nida (1993) describe the two meanings as to provide detailed information in a systematic manner' and 'to inform, to relate, to tell fully' (p. 411 ,
$\S 33.201$ ) and as 'to make fully and clearly known' and 'to make something fully known by careful explanation or by clear revelation' (p. 340, §28.41). which is almost a technical term in Greek literature, ${ }^{40}$ for the declaration of divine secrets by an oracle or a priest. ${ }^{41}$ The intransitive use of the verb in the aorist suggests that the introduction has been completed through a historical act (Phillips 2006:218-219). This would imply that through his life and exaltation, Jesus has shown the way to God. The Light has enlightened God. Schnackenburg (1980:279) refers to it as salvific revelation.

Also in both Hellenistic and Jewish religious environments, this verb was used to signify the communication of divine secrets. For the FE, this was the role of the $\lambda$ óros (Phillips 2006:219). It is thus that the FE can proclaim that the only

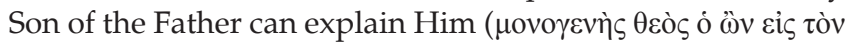

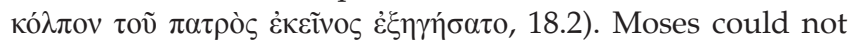
see all the glory of God because God declared that no one could see his face and live (Ex 33:20; cf. Keener 2003:424). ${ }^{42}$

Thus, for the only Son to 'make God known' implies much more than communicating a visual image; the verb $\dot{\varepsilon} \xi \eta \gamma \eta \dot{\sigma} \sigma \tau \mathrm{o}$ suggests that the Son fully interprets God: He unveils the character of God absolutely. This falls in the semantic field of light, visible, see, reveal, make known, etc.

Conclusion: The FE intentionally planned his vocabulary in verses $1-2$ and 18 to say something specific about the only Son

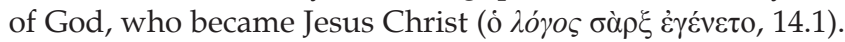
His intention was to apply this broad religious-philosophical category of the Logos to Jesus Christ. The FE introduces the Logos and identifies three of its characteristics in the following

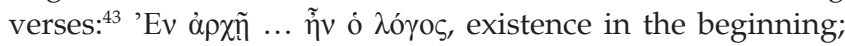

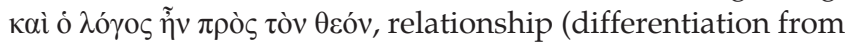

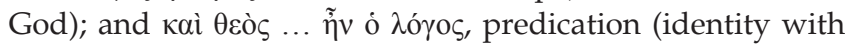

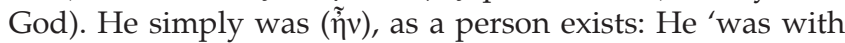

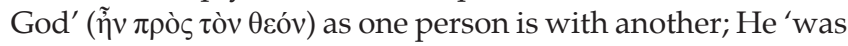

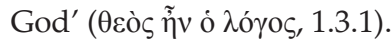

This section convincingly spells out the eternal relationship of the Logos or only Son of God with God the Father (cf. Schnackenburg 1980:233). The text in this section is linguistically loaded with evidence regarding his identity, pre-existence and relationship with God. Therefore, it closes with the theological concept of the revelation of the Father by his only Son. The FE tries to prove that Jesus is the Son of God, who alone can reveal (shed light on) God, and therefore through him alone, people can become children of God (enlighten) through faith in God's Son. Although, the light metaphor was not mentioned in this text, it is implied twice in verse 18 in $\dot{\varepsilon} \omega \rho \alpha \kappa \varepsilon v$ and $\dot{\varepsilon} \xi \eta \gamma \eta \dot{\sigma} \alpha \tau$ which falls in the same semantic field as 'light'.

\section{The Word or Light created everything or the world (cluster g)}

This section will examine the Word or Light's involvement in creation. Accordingly, the two references on creation through

40. Barrett (1975:141) points out that this usage corresponds with a major Greek use of the word.

41.Barrett (1975:141); Brown (1966:18); Lindars (1981:99).

42.Borgen (1968:145) states that verse 18 echoes Exodus 33:20.

43.Brown (1966:4) points out that since Chrysostom, scholars have recognised that each of the three uses of 'was' $\tilde{\eta} v$ in verse 1 has a different connotation. See also Phillips (2006:157). 
the Logos and the Light, in the first part of the prologue, are analysed to find out what kind of relationship exists between them.

\section{Semantic relations:}

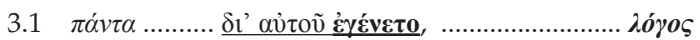

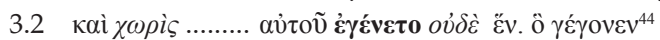

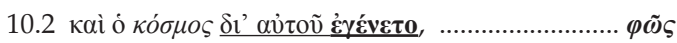

It is obvious that these three phrases are closely related due to

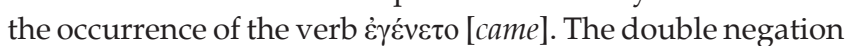
in $3.2(\chi \omega \rho i \varsigma . . . o b \delta \dot{\varepsilon})$ is used to emphasise the statement made in 3.1. Verses 3.1 and 10.2 are connected because they refer to the creation event.

Interpretation of related texts: Is Light the subject of creation in verse 10.2? How does verse 3.1 relate to 10.2 ? The reader is left here to supply the subject from the context. The initial alternative would be to continue with the assumption that the readers previously had to make in verse 9 that the subject is the $\lambda$ ó ${ }_{0} \varsigma-\theta \varepsilon \dot{s} \varsigma-\zeta \omega \eta \dot{-}-\varphi \tilde{\omega} \varsigma$ matrix. This decision is confirmed when the subject of verse 9 becomes the object of verse 10

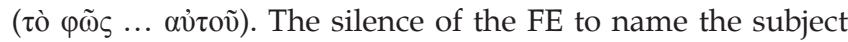
allows the reader to maintain the matrix in mind. ${ }^{45}$ Since verse 10 can only really refer to the involvement of the $\lambda$ ó ${ }^{\prime} \varsigma_{-}$ $\theta \varepsilon \dot{s} \varsigma \zeta \omega \grave{\eta}-\varphi \tilde{\omega} \varsigma$ matrix in the act of creation, the creative role of Light or Logos is confirmed here.

The FE repeats the key themes of verses $1-5$ in verse 10 . The similarities between verses $1-5$ and verse 10 are convincing. ${ }^{46}$ This then implies that verses 3.1 and 10.2 refer to the same act of creation.

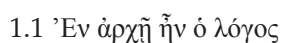

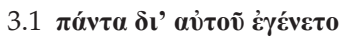

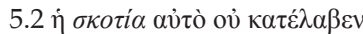

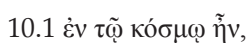

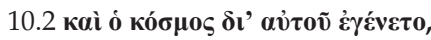

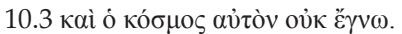

Hence, in verses 3.1,3.2 and 10.2 the FE involves $\lambda$ ó $\gamma_{0} \varsigma-\varphi \tilde{\omega} \varsigma$ in creation and history. His role is narrated in a passive sense:

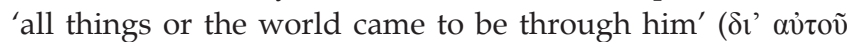

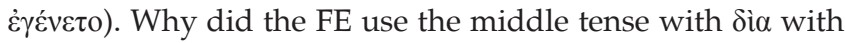
the genitive in both verses 3.1 and 10.2? It could be that the preposition is used predominantly to denote the instrument 'by which' something is done. It is also suggested that dì is used to denote the (intermediate) agent of an action, namely the one who acts. Hence, some ambiguity occurs whether $\delta$ ì $\alpha$ refers to an intermediate agent (Louw \& Nida 1993:797, $\S 90.4)$, an instrument by which something is accomplished

44.A text-critical problem occurs here. The division of words between $1: 3$ and 4 is

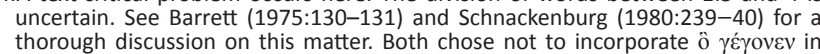
thorough discussion on this matter. Both chose not to incorporate ô $\gamma \varepsilon \dot{\gamma} \gamma$ ovEv in
verse 4 . Because their choice is convincing, it will be accepted as such in this study.

45.Phillips (2006:185). According to Dodd (1963:268) and Lindars ([1972]1981:90), a transition is made to $\varphi \tilde{\omega} \zeta$ in verse 4 . Now $\varphi \tilde{\omega} \zeta$ and no more $\lambda$ ó $\gamma \circ \zeta$ is formally the subject of the propositions made in verses 9-12. Phillips (2006:186) points out that the noun $\lambda$ ó $\gamma_{0} \zeta$ has not been used since the introduction of the noun $\phi \hat{\omega} c$, and the identification presumably is so strong that the two are interchangeable. Since the witness of John is to the Light, the reference to $\lambda$ ó $\gamma_{0} \varsigma$ has receded into the background until verse 14 .

46.Bultmann (1978:48) points out the similarities between these verses. Contrasts,

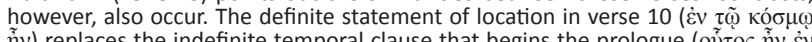
n) re

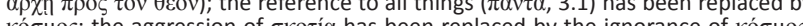

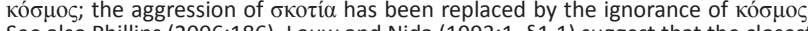
See also Phillips (2006:186). Louw and Nida (1993:1, §1.1) suggest that the closest

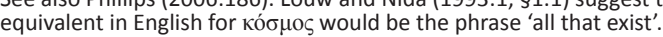

(Louw \& Nida 1993:798, §90.8), or the means by which one event makes another event possible (Louw \& Nida 1993:787, $\S 89.76)$. It can also refer to the origin or source in the case of $\delta i \alpha$ with the genitive (Blass \& Debrunner 1967:119, §223.3). This then implies that although Logos or Light is the intermediate agent of what comes to be, he is also the source.

So far in the prologue, the FE has used the verb civou (1-2), but the switch from description to narrative brings with it

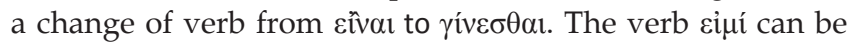
listed within the major domain 'be, become, exist, happen' and, in the first sub-domain, 'state' ${ }^{47}$ Here the emphasis is on

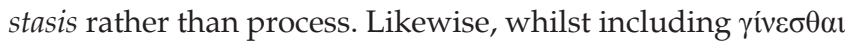
amongst stasis terms, the verb can also be listed in the second sub-domain, 'change of state', a sub-domain that focuses on terms involving process or change: to become, to change (cf. Louw \& Nida 1993:154). This would suggest that when both verbs are used in the same context, sivar would normally

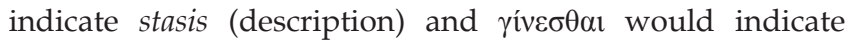
process (narrative).$^{48}$ In the opening verse of the prologue, Eivor has been used three times to express different elements of the pre-existence of the 'Logos' ${ }^{49}$ This infers that the use of Eivar moves towards what, in stasis, is eternal or beyond time. This places the introduction into eternity. The double use of

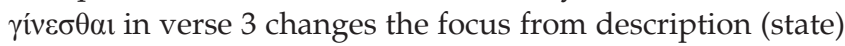
to narrative (change of state). This is a change from 'what was' in the beginning to 'what happened' next.

From this discussion it seems clear that $\gamma$ ive $\sigma \theta \alpha$ signals that 'all things came to be'. The understanding of this verb as a 'reference to creation' or to the 'entire course of history' is left to the reader to decide (Phillips 2006:161). Probably the FE tried to communicate that Logos brings about creation and also governs history. The account of Wisdom as the worker by the side of God at creation (Pr 8:22-31) is echoed in the prologue: the Logos or Light was the agent of all creation (vv. 3 and 10). Logos or Light in the prologue, like Wisdom or Torah, is God's agent of creation, a role that might also prefigure his role in the new creation. All things or Cosmos are or is intimately related to the Logos or Light, for it was created not only through him but also in him. (cf. Phillips 2006:161 $)^{50}$ The agent is distinct from the Creator: God the Father is viewed throughout the FG as the ultimate source of all.

Human beings were enlivened and illuminated by the Logos or Light, who was the source of life and light. The combination of life and light was so widespread in religious literature of early Christian times that one can speak of a 'liturgical formula' that combines life and light (Dodd 1963:19). All of this implies that because the Logos or Light

47.This is a highly generic domain indicating various aspects of states, and events (Louw \& Nida 1993:149).

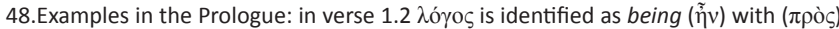

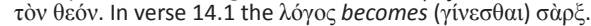

49.Brown (1966:4); Phillips (2006:157).

50.The same idea is found in Colossians 1:16: 'for in him were created all things in heaven and on earth ... all things were created through him and for him'. Cf. also Romans 11:36: 'everything there is comes from him and is caused by him and exists for him'. 
creates, the act of creation is not only the creation of the physical, but also an act of revelation and life. The perfect tense form, y'́rovev, at the end of verse 3.2 extends the work of the Logos from the creation throughout history into the time of the Fourth Gospel (Waetjen 2001:270). All creation bears the stamp of God's Logos or Light, whence the insistence in Wisdom 13:1 and Romans 1:19-20 that from his creatures God is recognisable by men (Brown 1966:25). It is possible that, for this reason, the FE incorporated the light motif here. The creation through the $\lambda$ ó ${ }^{\circ} \varsigma$ in verse 3.1 is equated with the creation through the Light in verse 10.2. Through the reference and incorporation of the 'Light also as agent' in the act of creation (and its connection with life, 4.2) the FE wants to indicate that God is observable and understandable also in creation.

Conclusion: In the above section, it was pointed out that the two references to creation $(3.1 ; 10.2)$ are parallel to and refer to the same creational event through one agent. The FE's use of $\delta$ ì with the genitive $\delta \iota^{\prime} \alpha$ ' $\tau$ ov depicts the Logos or Light as both agent and source of creation. The incorporation of Light into the creational act substantiates it not only as a physical creation, but also as an act of revelation and giving of life: God also reveals himself through nature.

\section{Conclusion}

The introduction referred to the dual approach of this research: the inner-textural and sacred-textural readings of the prologue. This research started off with an innertextural reading which consisted of a discourse analysis of the prologue of the Gospel of John to point out clearly a pictorial-logical structure. The research in the article followed the relevant semantic-cluster-network as indicated in the discourse analysis. This facilitated an investigation of the sacred texture to construe the pictorial theological interwovenness and to understand the prologue as an illumination-oriented construct in which the light metaphor was used in a constructive theological discourse.

In this article it became evident through the discourse analysis that various conceptual systems run throughout the prologue and are closely interwoven. Each system depends on the others in the sense that each could be used by itself as a model for representing and depicting Jesus; furthermore, every one of them leads to another. In his characterisation of Jesus, the FE utilises all these systems; he maps them onto one or more of the others. Consequently, an equivalence of the Logos and the light conceptual systems are established in the prologue: the first one (Logos) introduces the prologue, and the second one (light) has the highest occurrence in it. In this prologue, both of them are identified as agents of creation (vv. 3 and 10), entering the world (vv. 4, 9-10 and 14) and becoming the objects of 'receiving', 'knowing', 'believing', or of their contraries (vv. 5 and 10-12). The nouns 'Logos' and 'Light or light' refer to the same referent. It has been shown how the concept of light has been attached explicitly and implicitly to the identity and function of the Logos in the prologue. The Logos and the Light are also synonymous with the Life concept, which is said to have been 'in' है the Logos and to be 'the light of men' (vv. 3-4). Outside the prologue, the Logos system is absent, but the light system is closely associated with the Father or Son, Son of Man-Agent or discipleship systems.

Therefore, the light metaphor plays a major role in the interpretation and understanding of the prologue. Although the noun $(\varphi \tilde{\omega} \varsigma)$ and verb ( $\varphi \omega \tau i \zeta \varepsilon \imath)$ occur only in the first section (vv. 1-13) of the prologue, the chiastic structure and metaphoric denotation of 'light' show how it (light) saturates its influence and is embedded throughout the prologue. Through all this it is apparent that the light metaphor binds major themes in the prologue. It seems to be one of the key theological themes in the prologue which has a colligative effect to facilitate interpretation and understanding of the prologue and the rest of the FG.

In the prologue the FE deals with the nature, the character and the function of the Logos, which is personified in Jesus Christ. His being has been characterised in terms of the $\lambda$ ó $\gamma$ os$\theta \varepsilon \dot{\varsigma} \varsigma-\zeta \omega \grave{\eta}-\varphi \tilde{\omega} \varsigma$ matrix. Therefore the prologue is linguistically loaded with evidence regarding the Logos's identity, preexistence and relationship with God, and consequently closes with the theological concept of the illumination (revelation) of the Father by his only Son (the Light). The FE tries to prove that Jesus is the Son of God, who alone can reveal (illuminate) God (v. 18). The light metaphor is implied twice in verse 18 in $\dot{\varepsilon} \omega \rho \alpha \kappa \varepsilon v$ and $\dot{\varepsilon} \xi \eta \gamma \eta \dot{\sigma} \sigma \tau$ which fall into the same semantic field as $\varphi \tilde{\omega} \varsigma$. The incorporation of Light into the creational act substantiates it not only as a physical creation, but also as an act of revelation (enlightening) and giving of life (enlightenment): God also reveals himself through nature. This clearly points out the vastness of features attached to the light metaphor.

\section{Acknowledgements Competing interests}

The authors declare that they have no financial or personal relationship(s) which may have inappropriately influenced them in writing this article.

\section{Authors' contributions}

Both D.G.VdM. and P.Y.A. contributed to this article. D.G.VdM. provided his experiential inputs and revised the final product and was also responsible for the final editing, finishing touches and rounding off of the article.

\section{References}

Albalaa, P.Y., 2007, 'Light used as metaphor in the Prologue of the Fourth Gospel: The influence of this metaphor on the Maronite "Prayer of the Faithful",' M.Th. dissertation, Department of New Testament, University of South Africa, Pretoria.

Barrett, C.K., [1955] 1975, The Gospel according to St John. An introduction with commentary and notes on the Greek text, SPCK, London.

Blass, F. \& Debrunner, A., 1967, A Greek grammar of the New Testament, transl. R.W. Funk, The University Press of Chicago, Chicago.

Boismard, M-E., 1957, St. John's Prologue, transl. Carisbrooke Dominicans, Blackfriars, London. 
Borgen, P., 1968, 'God's Agent in the Fourth Gospel', in J. Neusner (ed.), Religions in Antiquity: Essays in memory of Erwin Remsdell Goodenough, Studies in the in Antiquity: Essays in memory of Erwin Remsdell Goodenough, Studies in the
history of religions, Supplements to Numen 14, pp. 137-148, Brill, Leiden.

Borgen, P., 1970, 'Observations on the Targumic character of the Prologue of John', New Testament Studies (16), 288-295.

Brown, R.E., 1966, The gospel according to John. A new translation with introduction and commentary, vol. I, Doubleday, New York.

Bultmann, R., [1966] 1978, The Gospel of John: A commentary, transl. G.R. BeasleyMurray, Blackwell, Oxford.

Burridge, R.A., 2007, Imitating Jesus: An inclusive approach to New Testament ethics, Eerdmans, Grand Rapids, Ml.

Cahill, P.J., 1976, 'Johannine Logos as center', QBC 38(1), 54-72.

Conzelmann, H., 1974, ' $\varphi \tilde{\omega} c^{\prime}$, in G. Friedrich (ed.), Theological Dictionary of the New Testament, Eerdmans, Grand Rapids, MI., vol. 9, pp. 310-358.

Culpepper, R.A., 1981, 'The pivot of John's Prologue', New Testament Studies 27, 1-31. http://dx.doi.org/10.1017/S0028688500010237

Dodd, C.H., 1963, Historical tradition in the Fourth Gospel, Cambridge University Press, Cambridge. http://dx.doi.org/10.1017/CBO9780511554919

Du Rand, J.A., 2000, 'Skeppingsgebeure in die Evangelieverhaal volgens Johannes' [Created events in the Gospel story according to John], Skrif en Kerk 21(2), 243259

Hengel, M., 2008, 'The Prologue of the Gospel of John as the gateway to Christological truth', in R. Bauckham \& C. Mosser (eds.), The Gospel of John and Christian Theology, pp. 265-294, Eerdmans, Grand Rapids, MI.

Hooker, M., 1970, 'John the Baptist and the Johannine Prologue', New Testament Studies 16, 357-381. http://dx.doi.org/10.1017/\$0028688500014065

Keener, C.S., 2003, The Gospel of John. A commentary, Vol. 1, Hendrickson Publishers, Peabody, Mass.

Koester, C.R., 2008, The Word of Life. A Theology of John's Gospel, Eerdmans, Grand Rapids, MI.

Kruse, C.G., 2003, John, The Tyndale New Testament Commentaries, vol. 4, Eerdmans, Grand Rapids, MI.

LaMarche, P., 1997, 'The Prologue of John (1964)', in J. Ashton (ed.), The Interpretation of John, pp. 47-66, T \& T Clark, Edinburgh.

Lincoln, A.T., 2005, The Gospel According to St John, Black's New Testament Commentary, vol. 4, Continuum, New York.
Lindars, B., 1981, The new century bible commentary. The Gospel of John, W B Eerdmans Publication Co, Grand Rapids.

Loader, W.R.G., 1984, 'The Central Structure of Johannine Christology', New Testament Studies 30, 188-216. http://dx.doi.org/10.1017/\$0028688500013758

Louw, J.P. \& Nida, E.A., 1993, Greek-English Lexicon of the New Testament based on semantic domains, United Bible Societies, Cape Town.

Malina, B.J. \& Rohrbauch, R.L., 1998, Social-Science commentary on the Gospel of John, Augsburg Fortress Publishers, Minneapolis.

Meeks, W.A., 1972, 'The Man from Heaven in Johannine Sectarianism', JBL 91, 44-72.

Morris, L., [1969] 1985, Studies in the Fourth Gospel, Eerdmans, Grand Rapids, MI.

Mullins, M., 2003, The Gospel of John. A commentary, The Columba Press, Dublin.

Neyrey, J.H., 2007, The Gospel of John, Cambridge University Press, Cambridge.

Petersen, N.R., 1993, The Gospel of John and the sociology of light: Language and characterization in the Fourth Gospel, Trinity Press International, Valley Forge.

Phillips, P.M., 2006, The Prologue of the Fourth Gospel. A sequential reading, Library of New Testament Studies 294, T \& T Clark, London.

Riches, J., 2005, 'Worship resources. Exegetical reflections on lectionary readings: Johannine Prologue', Expository Times 117(2), 69-73. http://dx.doi. org/10.1177/0014524605059892

Ridderbos, H., 1997, The Gospel of John. A theological commentary, Eerdmans, Grand Rapids, MI.

Robbins, V.K., 1996, Exploring the texture of texts: A guide to socio-rhetorical interpretation, Trinity Press International, Valley Forge.

Schnackenburg, R., [1968] 1980, The Gospel According to St John, vol. I, Burns \& Oates, London.

Van der Watt, J.G., 1991, 'Die Woord het mens geword: ' $n$ Strukturele uiteensetting van die teologie van die Johannesevangelie' [The Word turned into man: A Structural explanation of the theology of the gospel of John], in J.H. Roberts, W.S Vorster, J.N. Vorster \& J.G. Van der Watt (eds.), Teologie in Konteks [Theology in Context], pp. 93-130, Orion, Halfway House.

Van der Watt, J.G., 1995, 'The Prologue of John's Gospel: The historical Jesus introducing divine grace', Westminster Theological Journal 57(2), 311-332.

Waetjen, H.C., 2001, 'Logos pros ton Theon and the objectification of truth in the prologue of the Fourth Gospel', Catholic Biblical Quarterly 63(2), 265-286.

Whitacre, R.A., 1999, John, The IVP New Testament Commentary, Series 4, Intervarsity Press, Downers Grove, III. 


\section{Addendum 1}

\section{A proposed chiastic structure}

\section{Themes semantic relations}

\section{Speech is in the first person}

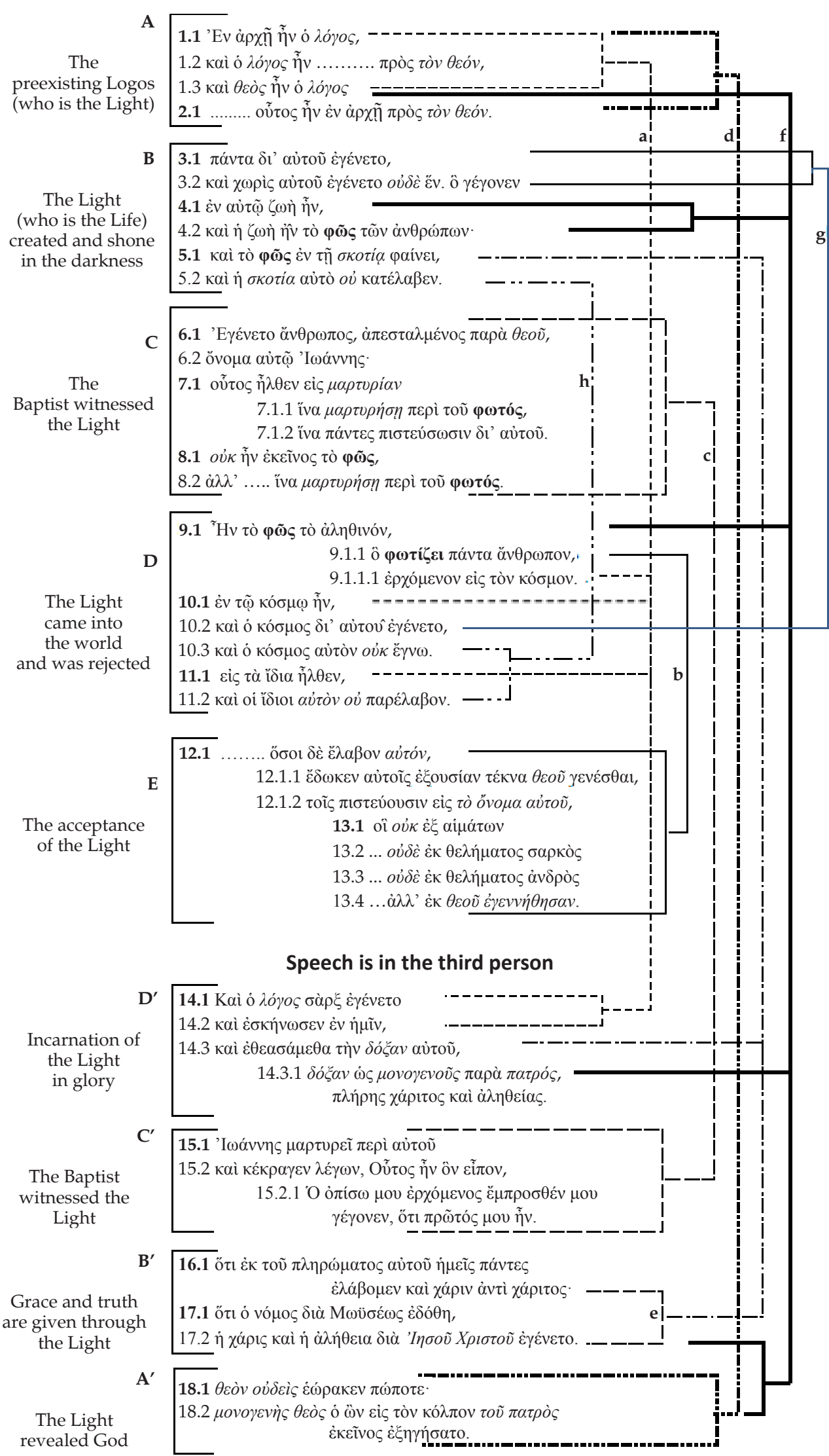

